Contributions to Zoology 


\section{Contributions to Zoology}

\section{Editor-in-Chief}

Ronald Vonk, Naturalis Biodiversity Center, Leiden, The Netherlands

\section{Associate Editor-in-Chief}

Bert Hoeksema, Naturalis Biodiversity Center, Leiden, The Netherlands

\section{Associate Editors}

Pim Arntzen, Naturalis Biodiversity Center, Leiden, The Netherlands - Ivana Buj, University of Zagreb, Croatia Denis Copilas-Ciocianu, Institute of Ecology, Nature Research Centre, Vilnius, Lithuania - Alexandra van der Geer, Naturalis Biodiversity Center, Leiden, The Netherlands - Danwei Huang, Tropical Marine Science Institute, Singapore - Ana Ivanović, University of Belgrade, Serbia - Herman de Jong, Naturalis Biodiversity Center, Leiden, The Netherlands - Michel Laurin, Muséum national d'Histoire naturelle, Paris, France - Alessandro Minelli, Università degli studi di Padova, Padua, Italy - Vincent Nijman, Brookes University, Oxford, UK - Flor T. Rhebergen, University of Amsterdam, Amsterdam, The Netherlands - Ronald Sluys, Naturalis Biodiversity Center, Leiden, The Netherlands - Rob van Soest, Naturalis Biodiversity Center, Leiden, The Netherlands - Ton de Winter, Naturalis Biodiversity Center, Leiden, The Netherlands

\section{Advisory Editorial Board}

Nick Barton, Institute of Science and Technology, Klosterneuburg, Austria - Bruno David, University of Burgundy, Dijon, France - David Harper, Durham University, Durham, UK - Michel Laurin, Muséum national d'Histoire naturelle, Paris, France - Katja Peijnenburg, Naturalis Biodiversity Center, Leiden, The Netherlands Hervé Philippe, Centre for Biodiversity Theory and Modelling, Moulis, France - Fred Schram, University of Washington, Seattle, USA - Geerat Vermeij, University of California, Davis, USA 


\section{Contributions to Zoology}

VOLUME 91 (2022)

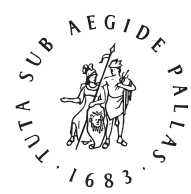

B R I L L 
Contributions to Zoology is an Open Access journal, which means that all content will be freely accessible online. All articles will be published under a non-exclusive Open Access license in exchange for an Article Publication Charge (APC). The author(s) keep full copyright and give(s) Brill permission to publish by signing a special Brill Open Consent to Publish form. The Brill Open Consent to Publish form will be sent by the responsible desk editor. For more information on Brill Open go to: brill.com/openaccess or contact brillopen@brill.com.

Typeface for the Latin, Greek, and Cyrillic scripts: “Brill”. See and download: brill.com/brill-typeface.

ISSN 1383-4517

E-ISSN 1875-9866

This is an Open Access journal distributed under the terms of the CC BY license at the time of publication, which permits any non-commercial use, distribution, and reproduction in any medium, provided the original author(s) and source are credited. Further information and the complete license text can be found at https://creativecommons.org/ licenses/by/4.o/. The terms of the Cc license apply only to the original material. The use of material from other sources (indicated by a reference) such as diagrams, illustrations, photos and text samples may require further permission from the respective copyright holder.

(C) Copyright 2022 by the author(s)

Koninklijke Brill NV reserves the right to protect the publication against unauthorized use and to authorize dissemination by means of offprints, legitimate photocopies, microform editions, reprints, translations, and secondary information sources, such as abstracting and indexing services including databases. Requests for commercial re-use, use of parts of the publication, and/or translations must be addressed to Koninklijke Brill NV.

This journal is published by Koninklijke Brill NV.

Koninklijke Brill NV incorporates the imprints Brill, Brill Nijhoff, Brill Hotei, Brill Schöningh, Brill Fink, Brill mentis, Vandenhoeck \& Ruprecht, Böhlau Verlag and V\&R Unipress.

This journal is printed on acid-free paper and produced in a sustainable manner. 